\title{
Comparison Analysis of Simple Additive Weighting (SAW) and Weigthed Product (WP) In Decision Support Systems
}

\author{
Dede Wira Trise Putra*, Adrian Agustian Punggara \\ Institut Teknologi Padang, Informatics Engineering Study Program, Padang, Indonesia
}

\begin{abstract}
Decision support system is a way to help decision maker to choose the best decision from several available alternatives. In the process of decision support system required criteria and weights to be used in the calculation process. Simple additive weighting (SAW) and Weigthed product (WP) are methods in decision support systems that have a search method taking into account the weights held by the criteria. comparison analysis is performed to look at between the WP and SAW methods, methods that have a higher level of accuracy and are in accordance with the conditions. The SAW method uses a weighted weaning system whereas the WP method uses multiplication in calculating the attribute rating. From the weight of each criteria there will be used in the calculation to produce several alternatives. The object of the case study in this study is the determination of people's business credit in the banking world using seven criteria. the criteria used are personal character, credit status, business condition, income, guarantee, guarantee condition and installment. Results of testing using SAW method and WP method, it can help compare the best alternative level results by using the same data and criteria, so both methods can be used as consideration in decision making. WP method gives clear cost and benefit value compared to SAW, but in SAW result gives more clear result because it is based on predetermined value and weight.
\end{abstract}

\section{INTRODUCTION}

\subsection{Background Issues}

Technological advances make the speed and accuracy in making decisions become a demand in the industrial world, one of which is the banking world. In the banking world the accuracy in decision-making by a decision maker will make a fast and effective data turnover such as on granting people's business loans to customers. In determining of eligibility is based on existing criteria. Effectiveness which is guided this time it is necessary to build a system that can help decision maker in making integration decision so that can help and simplify the bank in determining eligibility of accepted of People Business Credit so that execution can be faster [1].

Decision Support System (DSS) is one software product developed specifically to assist in decision making process. The purpose of this system is as "information source" or "second opinion" which can be used as consideration in decision making or certain policy. In the process of DSS of People's Business Credit will be done by comparing SAW method with WP method, both methods are chosen because both of these methods in the process to find the value finally must use a target value in the form of criteria and their weight, but in the process of using their own way. Compare of these two methods aims to determine the level of the best value using the same data and criteria $[2,3]$.
This SAW method requires the decision maker to determine the weight of each attribute. Total score for the attribute is obtained by summing all the resulted of the rated multiplication and the weight of each attribute. The rating of each attribute must be dimensionless in the sense that it has passed the process of normalizing the previous matrix. The advantages of SAW method of its ability to do the assessment more precisely because it is based on predetermined criteria and preference weights. While the WP method is a completion method by using multiplication to attribute attribute rating, where the rating must be raised first with the weight of the attribute in question. So that can know relevant method for giving credit by yielding Output order of priority the prospective customers who deserve to receive credit start from highest to lowest $[4,6]$.

\subsection{Research purposes}

The purpose of this study is to compare the highest level results using the same data and criteria between SAW and WP.

\section{Literature Review}

\subsection{Decision Support System}

\footnotetext{
* Corresponding author: dedewtp339@yahoo.com
} 
Decision Support System (DSS) is a computer-based information system that produces various decision alternatives to assist management in handling various structured or unstructured problems using data and models. The purpose of the DSS to support decisionmaking choose alternatived the results of information processing with decision-making models and to solve problems that are semi-structured and unstructured.

DSS is designed to assist decision-making in solving problems. DSS is designed in such a way that it can be used or operated easily by people who do not have basic high and alternative computer operating abilities, and DSS is designed with an emphasis on high adaptability aspects. [8].

\subsection{Simple Additive Weighting (SAW)}

The SAW method is often also known as the weighted summing method. The basic concept of the SAW method is to find the weighted sum of performance ratings on each alternative on all attributes. The SAW method requires the process of normalizing the decision matrix $(\mathrm{X})$ to a scale comparable to all existing alternative ratings. [5]. The formula for normalization is as follows:

$$
R i j=\left\{\begin{array}{l}
\frac{X_{i j}}{\operatorname{Max} X_{i j}} \\
\frac{\operatorname{Min} X_{i j}}{X_{i j}}
\end{array}\right.
$$

Information:

Rij : Performance alized performance rating.

Maxij : The maximum value of each row and column.

Minij : The minimum value of each row and column.

$\mathrm{Xij}$ : Rows and columns of the matrix.

With Rij is the normalized performance rating of $\mathrm{Ai}$ alternatives

The preference value for each alternative (Vi) is given as:

$$
V i=\sum_{j=1}^{n} W j r_{i j}
$$

Information :

$\mathrm{Vi}$ : The final value of the alternative

$\mathrm{Wj}$ : The specified weight

Rij : Normalization of the matrix

A larger value of $\mathrm{Vi}$ indicates that Ai's alternatives are preferred.

The advantages of the simple additive weighting method compared with other decision-making models lie in its ability to perform judgments more precisely because it is based on pre-defined value and preference weight.

\subsection{Weighted Product (WP)}

The Weighted Product (WP) method uses multiplication to attribute attribute rating, where the rating of each attribute must be raised first with the corresponding attribute's weights. This process is similar to the normalization process. [9].
Preferences for alternative Ai are given as follows:

$$
S i=\prod_{j=1}^{n} X_{i j}^{w j} ; \mathrm{i}=1,2, \ldots, \mathrm{m}
$$

Information:

Si: Vector Value Si

Xij: Alternatived Value against criteria

$\mathrm{Wj}$ : The weighted rank is positive for the profit attribute and is negative for the cost attribute

For calculating the relative preference values of each alternative, the following equations are given:

$$
V i=\frac{\prod_{j=1}^{n} X i j^{W j}}{\prod_{j=1}^{n}(X j)^{W j}} ; \mathrm{i}=1,2, \ldots \mathrm{m}
$$

Information:

Vi: The value of alternative preferences

Xij: Alternated attribute value

$\mathrm{Wj}$ : The value of the criterion weight

The advantages of this method can provide value and cost to the value of each Alternative.

Table 1. Personal Character Model

\begin{tabular}{|l|l|l|l|}
\hline No. & Criteria & Value & Weight \\
\cline { 1 - 3 } 1 & Good & 100 & \multirow{2}{*}{$10 \%$} \\
\hline 2 & Enough & 80 & \\
\hline 3 & Less & 50 & \\
\hline
\end{tabular}

Table 2. Credit Status Model

\begin{tabular}{|l|l|l|l|}
\hline No. & Criteria & Value & Weight \\
\hline 1 & Good & 100 & \multirow{2}{*}{$10 \%$} \\
\cline { 1 - 3 } & Middle & 80 & \multirow{2}{*}{10} \\
\hline 3 & Bad & 20 & \\
\hline
\end{tabular}

Table 3. Model of Business Conditions

\begin{tabular}{|l|l|l|l|}
\hline No. & Criteria & Value & Weight \\
\hline 1 & Good & 100 & \multirow{1}{*}{$25 \%$} \\
\hline 2 & Enough & 80 & \\
\cline { 1 - 2 } 3 & Less & 60 & \multirow{2}{*}{} \\
\hline 4 & Very less & 40 & \\
\hline
\end{tabular}

Table 4. Earnings Model

\begin{tabular}{|l|l|l|l|}
\hline No. & \multicolumn{1}{|c|}{ Criteria } & Value & Weight \\
\cline { 1 - 3 } 1 & $>5$ million & 100 & \\
\cline { 1 - 3 } 2 & $>4$ million -5 million & 80 & \multirow{2}{*}{$20 \%$} \\
\hline 3 & $>3$ million -4 million & 60 & \\
\hline 4 & $>2$ million -3 million & 40 & \\
\hline 5 & $0-2$ million & 20 & \\
\hline
\end{tabular}

Table 5. Guarantee Model

\begin{tabular}{|l|l|l|l|}
\hline No. & \multicolumn{1}{|c|}{ Criteria } & Value & Weight \\
\hline 1 & Car License & 75 & \multirow{2}{*}{$15 \%$} \\
\cline { 1 - 3 } 2 & Bike License & 75 & \\
\hline 3 & Building Certificate & 75 & \\
\hline
\end{tabular}


Table 6. Condition of Warranty

\begin{tabular}{|l|l|l|l|}
\hline No. & Criteria & Value & Weight \\
\hline 1 & Good & 100 & \multirow{1}{*}{$15 \%$} \\
\cline { 1 - 2 } 2 & Enough & 80 & \\
\cline { 1 - 2 } 3 & Less & 60 & \\
\hline 4 & Very less & 40 & \\
\hline
\end{tabular}

Table 7. Installment

\begin{tabular}{|l|l|l|c|}
\hline No. & Criteria & Value & Weight \\
\hline 1 & 12 month & 100 & \multirow{2}{*}{$5 \%$} \\
\cline { 1 - 3 } 5 & 24 month & 80 & \multirow{2}{*}{5} \\
\hline 3 & 36 month & 60 & \\
\hline
\end{tabular}

\section{Research}

\subsection{Simple Additive Weighting (SAW) Value Calculation}

Step in calculation SAW :

(1) Assessment criteria:

C1: Private Character

C2: Credit Status

C3: Business Condition

C4: Earnings

C5: Warranty

C6: Warranty Condition

C7: Installment

(2) The weighting of each Criterion

C1: $10 \%$ C2: 10\% C3: $25 \%$ C4: 20\% C5: $15 \%$ C6: $15 \%$ C7: $5 \%$

(3) Alternative Value Table

Table 8. Alternative Values

\begin{tabular}{|c|c|c|c|c|c|c|c|}
\hline \multirow{2}{*}{ Alt } & \multicolumn{7}{|c|}{ Criteria } \\
\cline { 2 - 8 } & $\mathbf{C 1}$ & $\mathbf{C 2}$ & $\mathbf{C 3}$ & $\mathbf{C 4}$ & $\mathbf{C 5}$ & $\mathbf{C 6}$ & $\mathbf{C 7}$ \\
\hline N1 & 80 & 100 & 80 & 100 & 75 & 100 & 80 \\
\hline N2 & 50 & 100 & 100 & 80 & 75 & 100 & 80 \\
\hline N3 & 100 & 80 & 80 & 60 & 75 & 60 & 60 \\
\hline N4 & 100 & 80 & 80 & 80 & 75 & 80 & 80 \\
\hline
\end{tabular}

(4) Perform normalization on the table by the formula (1)

$$
\begin{aligned}
& R 11=\frac{80}{\max (80: 50: 100: 100)}=\frac{80}{100}=0.8 \\
& R 21=\frac{50}{\max (80: 50: 100: 100)}=\frac{50}{100}=0.5 \\
& R 12=\frac{100}{\max (100: 100: 80: 80)}=\frac{100}{100}=1
\end{aligned}
$$

Etc.

Normalized table results :
Table 9. Normalization Table

\begin{tabular}{|c|c|c|c|c|c|c|}
\hline 0.8 & 1 & 0.8 & 1 & 1 & 1 & 1 \\
\hline 0.5 & 1 & 1 & 0.8 & 1 & 1 & 1 \\
\hline 1 & 0.8 & 0.8 & 0.8 & 1 & 0.6 & 0.75 \\
\hline 1 & 0.8 & 0.8 & 0.8 & 1 & 0.8 & 1 \\
\hline
\end{tabular}

(5) The final result is obtained from ranking the sum of the matrix multiplication $\mathrm{R}$ by the weights using the formula (2)

$$
\begin{aligned}
V 1=(0.8)(0.1) & +(1)(0.1)+(0.8)(0.25)+(1)(0.2) \\
& +(1)(0.15)+(1)(0.15)+(1)(0.05) \\
& =0.93
\end{aligned}
$$

$$
\begin{aligned}
V 2=(0.5)(0.1) & +(1)(0.1)+(1)(0.25)+(0.8)(0.2) \\
& +(1)(0.15)+(1)(0.15)+(1)(0.05) \\
& =0.91
\end{aligned}
$$

$$
\begin{aligned}
V 3=(1)(0.1)+ & (0.8)(0.1)+(0.8)(0.25) \\
+ & (0.8)(0.2)+(1)(0.15) \\
+ & (0.6)(0.15)+(0.75)(0.05)=0.82 \\
V 4=(1)(0.1)+ & (0.8)(0.1)+(0.8)(0.25) \\
& +(0.8)(0.2)+(1)(0.15) \\
& +(0.8)(0.15)+(1)(0.05)=0.86
\end{aligned}
$$

From the calculation using the SAW method obtained the highest end result is $\mathrm{V} 1=0.93$ (N1) with the best alternative value.

\subsection{Weighted Product (WP) Value Calculation}

Step in calculation WP :

(1) Assessment criteria:

C1: Private Character

C2: Credit Status

C3: Business Condition

C4: Earnings

C5: Warranty

C6: Warranty Condition

C7: Installment

(2) Giving weighted of each Criteria

Table 10. Criteria Table

\begin{tabular}{|c|c|l|l|}
\hline Value & Weight & Information & $\begin{array}{l}\text { Criteria } \\
\text { Weight }\end{array}$ \\
\hline 5 & $25 \%$ & Very Good & Highest \\
\hline 4 & $20 \%$ & Good & \\
\hline 3 & $15 \%$ & Enough & \\
\hline 2 & $10 \%$ & Less & \\
\hline 1 & $5 \%$ & Very Less & Lowest \\
\hline
\end{tabular}

then the weighting is $\mathrm{W}=\{2,2,5,4,3,3,1\}$

with

$$
\begin{aligned}
& W 1=\frac{2}{2+2+5+4+3+3+1}=\frac{2}{20}=0.1 \\
& W 2=\frac{2}{2+2+5+4+3+3+1}=\frac{2}{20}=0.1
\end{aligned}
$$




$$
\begin{aligned}
& \begin{array}{c}
W 3=\frac{5}{2+2+5+4+3+3+1}=\frac{5}{20} \\
=0.25
\end{array} \\
& W 4=\frac{4}{2+2+5+\frac{4}{3}+3+3+1}=\frac{4}{20}=0.2 \\
& W 5=\frac{3}{2+2+5+4+3+3+1}=\frac{3}{20} \\
& =0.15 \\
& W 6=\frac{3}{2+2+5+4+3+3+1}=\frac{3}{20} \\
& =0.15 \\
& W 7=\frac{1}{2+2+5+4+3+3+1}=\frac{1}{20} \\
& =0.05
\end{aligned}
$$

(3) Alternative Value Table

Table 11. Alternative Values

\begin{tabular}{|c|c|c|c|c|c|c|c|}
\hline \multirow{2}{*}{ Alt } & \multicolumn{7}{|c|}{ Criteria } \\
\cline { 2 - 8 } & C1 & C2 & C3 & C4 & C5 & C6 & C7 \\
\hline N1 & 80 & 100 & 80 & 100 & 75 & 100 & 80 \\
\hline N2 & 50 & 100 & 100 & 80 & 75 & 100 & 80 \\
\hline N3 & 100 & 80 & 80 & 60 & 75 & 60 & 60 \\
\hline N4 & 100 & 80 & 80 & 80 & 75 & 80 & 80 \\
\hline
\end{tabular}

(4) Preferences for alternative Ai are calculated by the formula (3) as follows:

$S 1$

$=\left(80^{0.1}\right)\left(100^{0.1}\right)\left(80^{0.25}\right)\left(100^{0.2}\right)\left(75^{0.15}\right)\left(100^{0.15}\right)\left(80^{0.5}\right)$ $=87.6$

$S 2$

$=\left(50^{0.1}\right)\left(100^{0.1}\right)\left(100^{0.25}\right)\left(80^{0.2}\right)\left(75^{0.15}\right)\left(100^{0.15}\right)\left(80^{0.5}\right)$

$=84.5$

S3

$=\left(100^{0.1}\right)\left(80^{0.1}\right)\left(80^{0.25}\right)\left(60^{0.2}\right)\left(75^{0.15}\right)\left(60^{0.15}\right)\left(60^{0.5}\right)$

$=72.2$

S4

$=\left(100^{0.1}\right)\left(80^{0.1}\right)\left(80^{0.25}\right)\left(80^{0.2}\right)\left(75^{0.15}\right)\left(80^{0.15}\right)\left(80^{0.5}\right)$ $=81$

(5) To obtain the final result using the formula preferences (4) :

$$
\begin{gathered}
V 1=\frac{87.6}{87.6+84.5+72.2+81}=\frac{87.6}{325.3} \\
=0.269 \\
V 2=\frac{84.5}{87.6+84.5+72.2+81}=\frac{84.5}{325.3} \\
=0.259 \\
V 3=\frac{72.2}{87.6+84.5+72.2+81}=\frac{72.2}{325.3} \\
=0.221 \\
V 4=\frac{81}{87.6+84.5+72.2+81}=\frac{81}{325.3} \\
=0.249
\end{gathered}
$$

From the calculation using Weighted Product method obtained the highest final result is V1 $=0.269$ (N1) with the best alternative value.

\section{Testing and Results}

Tests using SAW and WP methods were conducted using 10 customer data applying for credit. The customer data used is taken randomly based on data owned by the bank. After the data to be used has been assigned a value on each criteria, then the next step is done as in the explanation in section 3 above.

Based on these tests then obtained the results as the following table 12 .

Table 12. Comparison of SAW and WP results

\begin{tabular}{|c|l|c|c|}
\hline No & $\begin{array}{c}\text { Prospective } \\
\text { Customer }\end{array}$ & $\begin{array}{c}\text { SAW } \\
\text { Score }\end{array}$ & WP Score \\
\hline 1 & Cstr 1 & 0.785 & 0.0355 \\
\hline 2 & Cstr 2 & 0.7825 & 0.0347 \\
\hline 3 & Cstr 3 & 0.75 & 0.0343 \\
\hline 4 & Cstr 4 & 0.735 & 0.0346 \\
\hline 5 & Cstr 5 & 0.725 & 0.0343 \\
\hline 6 & Cstr 6 & 0.725 & 0.0343 \\
\hline 7 & Cstr 7 & 0.7225 & 0.0335 \\
\hline 8 & Cstr 8 & 0.7125 & 0.0333 \\
\hline 9 & Cstr 9 & 0.7125 & 0.0333 \\
\hline 10 & Cstr 10 & 0.7125 & 0.0333 \\
\hline
\end{tabular}

The scores that are matches in the table above have been sorted from the highest to lowest values. From these results the highest value becomes the highest alternative for decision makers to be worthy or not prospective customers approved credit loan proposal.

In the table cstr 3 and cstr 4 have different scores. In cstr 3 score on SAW is higher when compared with score on WP. While in cstr 4 WP score higher when compared with SAW score.

This is due to the difference of the cost and benefit value of each method. In SAW the value of cost and benefit in the form of the value of Max for benefit, Min for cost on the whole data. While the weighting criteria given based on the value and weight preference that has been determined. In weighted product the cost and benefit value is given in the form of plus for benefit and minus for cost, on weighted product weight for given criterion based on weighted value rankings the highest.

At these results, when decision maker is done make a decision then the results taken as the final decision is the score of SAW method based on the criteria used in data processing. So for the end result simple additive weighting gives more clear results than the weighted product because it is based on the value and weight preference that has been determined.

\section{Conclusions and Recommendations}

Results of the research can be concluded as follows :

(1) Simple Additive Weighting and Weighted Product method that has been done the calculation shows 
differences in ranking results on the alternative obtained based on the same criteria and data that aims to find the best alternative.

(2) Results of rankings produced by both methods are not always the same because of the differences in the cost and benefit value of each method, whereby the WP provides more clear cost and benefit value than SAW, but on the results SAW gives more result more clearly than WP because it is based on predetermined value and weight.

(3) Simple Additive Weighting method is more suitable for use in credit cases where the results given are more obvious because they are based on predetermined assessments and weights.

(4) SAW and WP methods can be compared with other DSS methods and can use more data samples.

\section{References}

1. D.W.T. Putra, M. Epiyanto. Sistem Pendukung Keputusan Pemilihan Sepeda Motor Jenis Sport 150cc Berbasis Web Menggunakan Metode Analytical Hierarcy Process (AHP). Journal Teknoif, 5 (2), 1624. (2017)

2. F. Azwary, Sistem Pendukung Keputusan Pemberian Kredit Usaha Rakyat Pada Bank Syariah Mandiri
Cabang Medan Menggunakan Metode AHP. Medan: Universitas Sumatera Utara. (2010)

3. F.L. Fadly, Sistem Pendukung Keputusan Pemberian Kredit Motor Menggunakan Metode Simple Additive Berbasis Web (Studi Kasus: PT. FIF Group Simpang Empat Pasaman Barat). Padang: Institut Teknologi Padang. (2015)

4. Fitira. Analytic Hierarchy Process Metode Pendukung Keputusan Pemberian Kredit Pada Koperasi Mandiri Utama. Bandar Lampung: Institut Informatika dan Bisnis Darmajaya. (2013)

5. Haswan, Febri. Decision Support System For Election Of Members Unit Patients Pamong Praja. (2017)

6. Kusrini. Konsep dan Aplikasi Sistem Pendukung Keputusan. Yogyakarta: Andi Offset. (2007).

7. E. Turban et al. Decision Systems and Intelegent Systems (Sistem Pendukung Keputusan dan Sistem Cerdas) Edisi 7 Jilid 1. Yogyakarta: Penerbit Andi. (2005)

8. S.K. Dewi, Fuzzy Multi Attribute Decision Making (Fuzzy MADM). Yogyakarta: Graha Ilmu. (2006).

9. N. Aini et al. Penerapan Metode Weighted Product dan Analytic Hierarchy Process Untuk Pemilihan Koperasi Berprestasi. Samarinda: Universitas Mulawarman. (2017) 